\title{
New Perspectives of Using The Communicative Approach in Teaching Short Story \\ By
}

Asst. Lecturer Manaal Jassim Muhammad

College of Education (Ibn Rushd)

University of Baghdad

\subsection{Introduction}

Lack of communication sets up barriers between teachers and learners of EFL. These barriers have different shapes and list several problems. In the majority of cases, Iraqi EFL learners lack the ability to speak and write English fluently. Thus, it is harder to understand than it needs to be. Widdowson indicates that

The problem is that students and especially students

who have received several years of formal English teaching, frequently remain deficient in the ability to actually use the language, and to understand its use, in normal communication, whether in the spoken or the written mode. (Brumfit and Johnson, 1979: 117)

The Problem is that some teachers may still believe that teaching EFL encompasses focusing on linguistic aspects only, while others who teach literature have realized that literature adds a new dimension to the teaching of EFL. Teaching short stories, for example, help students learn the integration of the four skills: listening, speaking, reading, and writing more effectively because of the motivational effects embedded in the stories.

Since the goal of ELT courses is to help students to develop their skills in the target language, teachers should focus on communicative aspects of language rather than on mere mastery of structures. Broadly what is needed is a shift of the focus of attention from the structural to communicative properties of the language. The purpose of the present study is to familiarize Iraqi EFL teachers with the effectiveness of using the communicative approach (henceforth CLT) in teaching short story as well as planning motivating-work classes that really meet the needs, interests, and tastes of Iraqi EFL learners. The study argues that using certain 
techniques of CLT in short story context is stimulating for both teachers and learners of EFL. Furthermore, selecting short stories that are appropriate to students' level of proficiency and preferences will certainly be motivating.

\subsection{Communicative Language Teaching}

Crystal (1992: 74) defines the communicative approach as follows

$$
\begin{aligned}
& \text { an approach to language teaching which focuses on } \\
& \text { language functions and communicative competence } \\
& \text { and not on grammatical structure. The emphasis is on } \\
& \text { the processes involved in actual communication, and } \\
& \text { on the appropriate use of language in real situations. }
\end{aligned}
$$

The communicative approach in language teaching starts from a theory of language as communication. The principal aim is to develop the learner's competence (Chomsky's term) by means of controlled performance. The assumption behind this approach is that learning a language is a matter of associating the formal elements of the language system with their physical realization, either as sounds in the air or as marks on paper. The origins of the communicative approach are to be found in the changes in the British language teaching traditions dating from the late 1960s.

British applied linguists used studies of the needs of European language learners. D. A. Wilkins (cited in Richards and Rodgers, 1986: 64) prepared a preliminary document which proposed a functional or communicative definition of language that could save as basis for developing communicative syllabuses for language teaching. Wilkins's contribution was an analysis of the communicative meanings that a learner needs to understand and express. He saw the need to focus in language teaching on communicative properties rather than on grammatical aspects. Scholars who advocated this view of language teaching are (Christopher Candlin and Henry Widdowson) who drew on the works of British Functional linguists (e.g. John Firth, M. A. K. Halliday), American work in sociolinguistics (e.g. Dell Hymes, John Gumperz, and William Labov), as well as work in philosophy (e.g. John Austin and John Searle). Both American and British 




linguists now see communicative language teaching as an approach that aims at a) promote a knowledge of the language system by making communicative competence the goal of language teaching and b) develop procedures for teaching of the four language skills that acknowledge the interdependence of language and communication,"One of the most characteristic features of communicative language teaching is that it pays systematic attention to functional as well as to structural aspects of language"(Littlewood,1981: 1).

Several roles are assumed for teachers in Communicative Language Teaching (CLT). The importance of particular roles is determined by the view of CLT adopted. Breen and Candlin describe teacher roles as follows:

The teacher has two main roles: the first role is to facilitate the communication process between all participants in the classroom, and between these participants and the various activities and texts. The second role is to act as an independent participant within the learning-teaching group.

(Cited in Richards and Rodgers, 1986: 77)

Other terms denoting the same linguistic phenomenon are notional-functional approach and functional approach:

A notional approach allows us to regroup the structures in a different way from that in which they were originally introduced. This not only adds a desirable element of novelty to the learner's activity but enables him to recognize his knowledge of the language in a meaningful way by reference to semantic principles. (Allen and Corder, 1975: 91)

\subsection{The Teaching of Short Stories as Communication}

Literature can motivate students to read and write more creatively. It can be used to develop the skills and complement language teaching. Literary texts are often more interesting than texts found in course books. Teachers can use short stories, for example, for language practice, reading comprehension and possible aesthetic 
appreciation at beginning and intermediate levels. In contrast, with high intermediate and advanced levels, short stories can be utilized for getting knowledge of literature, practice in reading, discussing creative work, and the introduction of literary concepts like recognition of figures of speech, levels of meaning, and other stylistic aspects. Moreover, short stories are effective in teaching critical thinking and culture to EFL learners.

\subsection{Advantages of Short Stories}

Researchers who advocate the use of short stories in ELT context list several benefits of short stories. These include motivational, cultural, literary, higher-order thinking, and, above all, reinforcement of skills. However, before novice teachers attempt to use short stories in ELT classes, they should understand the benefits of short stories and plan motivating work classes that really meet the needs of students.

\subsubsection{Reinforcing the Skills}

Short stories allow teachers to create various activities that teach the four skills to all levels of language proficiency. Murdoch (2002: 4) expounds that "short stories can, if selected and exploited appropriately, provide quality text content which will greatly enhance ELT courses for learners at intermediate levels of proficiency."

Therefore, by selecting short stories, teachers should avoid frustrational readings. Short stories should be chosen according to students' level of proficiency and preferences. Short stories, thus, should have various themes since variety of themes will offer different things to many individuals' interests and tastes. Moreover, the themes should be consistent with the traditions that the learners are familiar with.

The range of exercise types and activities compatible with a communicative approach is unlimited, provided that such exercise enable learners to attain the communicative objectives of the curriculum, engage learners in communication, and require the use of such communicative processes as information sharing, negotiation of meaning, and 
interaction classroom activities are often designed

to focus on completing tasks that are mediated

through language or involve negotiation of

information and information sharing. (Richards and Rodgers, 1986: 76)

Murdoch (2002) explains why short stories should be used to reinforce ELT by discussing activities teachers can create such as writing skills and acting out dialogues. Short stories can be used to improve students' vocabulary and reading. Lao and Krashen (2000) present the result of a comparison between a group of students that read literary texts and a second group that read non-literary texts at a university in Hong Kong. The group who read literary texts showed improvement in vocabulary and reading (see Section 2.4.3)

\subsubsection{Motivating Students}

Literature is motivating students to read and write more creatively. Materials thus have the primary role of promoting communicative language use. Elliot (1990: 197) states that "literature motivates students and is motivationally effective if students can genuinely engage with its thoughts and emotions and appreciate its aesthetic qualities." Short stories usually have a beginning, middle, and an end, so they encourage students to continue reading them until the end to find out how the conflict is resolved. In addition, one of the reasons for using short stories in ELT context is that short stories motivate students to explore their feelings through experiencing those of others. Students can feel a real sense of achievement at understanding a piece of literature. Also, literary texts are often more interesting than texts found in course books. As a result, teachers should give students the opportunity to express their own insights, helping them to speak in a more imaginative way. Students become more creative since they are faced with their own point of view. This thoughtful process could lead students to critical thinking, "focusing on point of view in literature enlarges students' vision and fosters critical thinking by dramatizing the various ways a situation can be seen" (Oster, 1989: 85). Therefore, when students read they interact with the text. By interacting with 
the text, they interpret what they read. By interpreting what they read, they can work towards speaking English more creatively.

\subsubsection{Motivating Higher-Order Thinking}

Of all the benefits of teaching short stories, higher-order thinking is the most exciting one. Short stories encourage students to think critically and analyse what they read. There are two crucial advantages of short stories over traditional content: first because they are entertaining, students' pervasive apprehension is reduced and they learn from the beginning that critical thinking is natural and familiar. Second, the stories put issues of critical thinking in an easily remembered context. Teachers thus have the responsibility to develop students' cognitive skills since every student needs to make judgements, be decisive, come to conclusions, organize, evaluate, predict, and apply knowledge.

Bloom et al., in 1956, introduced Bloom's taxonomy of cognitive skills. This taxonomy includes both lower-order and higher-order thinking, depending on students' level of proficiency. Bloom et al. classify four levels of thinking skills:

Level 1: when students are asked questions about names of characters, dates, places, events, setting, and plot of the text. Beginners (loworder thinking) will have no difficulties to answer such questions.

Level 2: (comprehension), in this level, students must demonstrate their comprehension by comparing, interpreting, giving descriptions, and stating main ideas.

Level 3: (application), in this level, students try to solve problems by using the knowledge they have about the text.

Level 4: (analysis), in this level, students must have reached the high intermediate level of proficiency. They must analyze, compare, contrast, explain, infer, etc. facts / ideas about the story.

Having reached the advance level of proficiency, teachers can ask questions like:

Q 1. In the story The Man Who Planted Trees, would it have made any difference if Elzéard Boufier didn't plant the oak trees? 


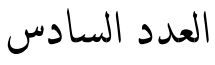

This question requires students to think of a different end to the same story.

Q 2. Do you agree with the way Elzéard Bouffier acted?

Q 3. Do you agree with the resolution of the story? Questions (2 and 3) require students to make judgement. (See Appendix)

\subsubsection{The Role of Teaching Culture}

Short stories are effective in teaching culture to EFL learners. When using literary texts, teachers must be aware that the culture of the people for whom the text is written should be studied. By learning about culture, students learn about the past and present, and about people's customs and traditions. As students face a new culture, they start comparing it to their culture to find similarities or differences between the two cultures. The new culture makes them more aware of their own culture. Thus, teachers should introduce culture to students to "get knowledge," and to avoid "misinterpretation". As Goodenough points out:

\footnotetext{
We must take "knowledge" here in a broad sense, to include both "know-how" and "know-that," for instance, to cover both the ability to tie knots and the knowledge that one pound coin buys as much as ten ten penny coins. One attraction of taking this view, widely accepted among anthropologists, is that it will allow us to compare culture with language, which we are also taking to be a kind of knowledge.
}

(Cited in Hudson, 1996: 71)

\subsection{Data Collection}

This section outlines the steps and procedures adopted in carrying out the fieldwork of this study. It deals with the corpus, the sample of the study, planning the lesson, performance and appreciation.

\subsubsection{The Corpus}

The researcher had taught five short stories and gained specific experience when making a lesson relevant to communicative approach. Out of them, only one short story entitled The Man who Planted Trees, written by the French writer Jean 
العدد السادس

Giono (1895-1971), has been chosen to illustrate the points in question. In it, Giono describes the world of a solitary shepherd who plants trees, while in the background there are two world wars.

\subsubsection{The Sample of the study}

The sample of the study is a group of (20) officials working at the Ministry of Foreign Affairs. The researcher is assigned to give a course there in English language teaching as part of the requirements of the Foreign Affairs Ministry to develop the language skills of its staff members. The whole group (50) is selected randomly in terms of degrees, age, native language, and linguistic background. Most of them have degrees in political sciences, law, and languages. Those who have bachelor degree in English language are excluded.

After conducting a test, the whole group is divided into two levels, preintermediate level (30 students) and intermediate level (20 students). Each group constitute one section. The researcher is assigned to teach the intermediate level. The course lasts (2) months, from 15/3/2006-15/5/2006. Each group has taken a minimum of (75) hours, 9 hours per week, 3 hours per day with tea time (30 minutes). The course aims at developing language skills, listening, speaking, reading, and writing. To achieve this, typical motivating work classes have been planned. The range of activities, exercise types, simulation, and task-based communicative skills have been prepared to support Communicative Language Teaching classes.

\subsubsection{Lesson Planning}

The present section describes typical classroom procedures used in a lesson based on CLT principles.

\subsubsection{Reading Tasks}

One of the things to bear in mind when planning a lesson is that classroom reading is not the same as real reading. Classroom reading aims at helping students develop the skills they need to read more effectively in a variety of ways. To achieve this, teachers should plan "pre-reading," "while-reading," "reading 
العدد السادس

comprehension," and "post-reading tasks". These activities can help teachers make reading more effective. Reading is, of course, just as communicative as any other form of language use and the teacher's aim is to bring out that communicative element.

\section{a) Pre-reading Task}

Pre-reading tasks often aim to raise the reader's knowledge of what they are about to read (their schematic knowledge) as this knowledge will help them to understand the text. In pre-reading activities, students have the opportunity to learn about the background of the text and teachers can start by asking students questions before they are introduced to the text. Read the following quotation: "only when the last tree has died and the last river has been poisoned and the last fish has been caught will we realize that we cannot eat money."

1. Who do you think said it?

a. A political leader.

b. A member of Green Peace.

c. An American Indian.

d. An African Fisherman.

e. A Greek philosopher.

f. A French farmer.

2. When do you think it was said?

a. In the $5^{\text {th }}$ century $B C$.

b. In the $9^{\text {th }}$ century

c. In the $15^{\text {th }}$ century

d.In the $17^{\text {th }}$ century

e. In the $19^{\text {th }}$ century.

f. In the $20^{\text {th }}$ century.

\section{b) While-reading task}

Jigsaw reading is an old favourite but perennially effective. The activities within this task includes the following steps: 
العدد السادس

1. The teacher reads the story out loud to help students have the opportunity to listen and read (books open) with the teacher. This activity is done for students to find answers to questions given and explained to them in pre-reading task.

Then the teacher does the following:

2. Divide the class into four groups, A, B, C, and D.

3. Group A get extract (1), group B get extract (2), group C get extract (3), and group D get extract (4). Each group should read their extract and answer the tasks related.

4. Group A complete their tasks in a group. Groups B, C, and D likewise.

5. Students get into A and B, C and D pairs and tell each other about their answers.

The tasks assigned are related to form, meaning, and use respectively:

\section{1) Form}

Complete the word form in the following chart. The first word has been done for you. Remember that some words do not have all forms.
$\underline{\text { Verb }}$
$\frac{\text { Noun }}{\text { speaker }}$
adjective
$\underline{\text { Adverb }}$
1. speak
speakable
2. grow
3. -------
rest
4.

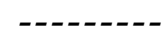
actual
5.
notice
6. insist
7.
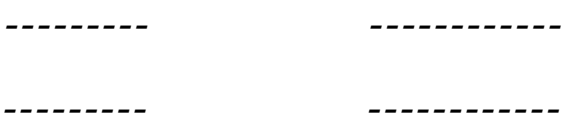
effect
9.


changeable
10.
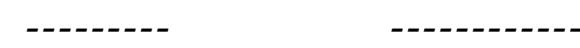
imperturbably
11. die
12.

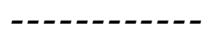
extremely

There can be as many words as the teacher thinks necessary, but s/he should not dig deep down so as not to make students lose interest in the activity that should 
العدد السادس

be included in every story. This activity helps students to learn more vocabulary, and it also leads them to know how to use a dictionary.

\section{2) Meaning}

a) Match the following adjectives with their synonyms. Work in groups:

\begin{tabular}{|l|l|}
\hline \multicolumn{1}{|c|}{$\mathrm{A}$} & \multicolumn{1}{|c|}{$\mathrm{B}$} \\
\hline barren & attractive \\
insistent & left \\
magnificent & calm \\
disturbed & surprising \\
imperturbable & determined \\
abandoned & empty \\
amazing & affected \\
& \\
\hline
\end{tabular}

b) Match the following adjectives with their opposites:

\begin{tabular}{|l|l|}
\hline A & \multicolumn{1}{|c|}{$\mathrm{B}$} \\
\hline barren & alive \\
interested & bored \\
imperturbable & nervous \\
young & fertile \\
harsh & wet \\
dry & gentle \\
dead & old \\
& \\
& \\
\hline
\end{tabular}

In activity (a) the words in column A come from the story students are reading. The synonyms provided in column B must match the meaning of the words in the context of the story to help students understand how a different word can be used in the same context. 


\section{3) Use}

1. Must, could, might, and can't are used to express degrees of probability about the present:

He must be in love. (Very probable that he is in love). $95 \%$.

He could be in love.

He might be in love $45 \%$

(Possible, but less probabl).

He can't be in love. (Very probable that he is not in love. $95 \%$.

Note "can't" is the negative form of "must".

2) they are used to express degrees of probability about the past (using the perfect tense).

He must have been in love. (Very probable that he was in love.)

He could have been in love.

He might have been in love. Possible, but less probable

He can't have been in love. (Very probable that he was not in love).

Teacher: Now read the story (all groups) and find examples of similar usage.

\section{c) Comprehension Check}

As far as reading comprehension is concerned, the new vocabulary (indicated above 2(a, b) will help students with comprehension.

Teacher-Work in groups.

\section{Group A. Extract (1).}

1. Giono wrote the story in 1953; in which year does the actual story begin?

2. The story takes place in France, which part of France do you think it is? Why? What is the countryside like?

3. Why do you think the writer is interested in the shepherd? What do you think he likes about his life style? 


\section{Group B. Extract (2).}

4. How old do you think the writer was at the time of the story? A boy in his teens? In his twenties? Middle-aged? Older? Why?

5. How old will Elzéard be in thirty years' time? What year will it be?

6. What do you think Elzéard's ambition is? What is his vision of the future?

\section{Group C. Extract (3).}

7. Why did the writer think that Elzéard might have died?

8. How had the war affected Elzéard?

9. Why is the writer speechless?

10. What thoughts about human behaviour does he have in the last sentence?

\section{Group D. Extract (4).}

11. What has happened in the writer's life that could have made him pessimistic? Is he in fact pessimistic about the world? Give a reason for your Answer.

12. How is it that so many people owe their happiness to one man? What are the results of his tree-planting?

13. How old is Elzéard when he dies? Why is it so important that he had a long life?

\subsubsection{Speaking Tasks}

a. Do you think the story about Elzéard is true?

b. Do you think Elzéard was ever married? Give reasons for your opinions.

c. How do you describe the personality of Elzéard Bouffier? Do you know any people like him in your life?

d. In the context of the twentieth century and its two world wars, what message is Giono trying to make about nature and the importance of individual human being? 
e. Man could be as effective as god in ways other than destruction. Discuss in pairs, then in Groups.

\subsubsection{Writing Tasks}

Having reached advanced level in understanding the story, teachers can create a variety of writing activities to help students develop their writing skills. Oster (1989: 85) affirms that "literature helps students to write more creatively." Teachers can assign the following activities:

\section{Work in Groups}

a) Read the following sentences about Elzéard Bouffier and then re-write them with a paragraph? Pay attention to the ways in which you combine sentences.

1. Elzéard Boufier was a shepherd.

2. He was poor.

3. He was solitary.

4. He lived in the mountains.

5. The mountains were barren.

6. They were in southern France.

7. Elzéard had a love of nature

8. He had an incredible idea

9. During his life he planted thousands of acorns.

10. The acorns grew into a forest of oak trees.

11. The forest made the countryside rich and fertile again.

12. He died when he was 89 .

b) The story is written in the past tense. Re-write it in the present.

c) 1. Write a dialogue between the writer and Elzéard Bouffier?

2. Paraphrase the first paragraph of the third extract.

3. Write one sentence on the theme of the story.

4. Summarize the story in 5 sentences including the main character, setting, conflict, and resolution. 


\subsubsection{Performance and Appreciation}

The students' overall performance is satisfactory, particularly in "reading" and "speaking" tasks. They show enthusiasm and energy to interact within the new techniques of CLT, the group, and within the classroom procedures and activities which the group undertakes. The role of learner is as negotiator within the group, the class, the learning process, and the object of learning. This clearly verifies what has been said forward in section (1.1) which is to the effect that using certain techniques of CLT in teaching short stories that are appropriate to students' level of proficiency and preferences is stimulating for both teachers and learners of EFL. The written practice, on the other hand, shows students' inability to write a successful piece of writing. Analysis of (20) paragraphs written by the sample (task C. No. 2, 4) has identified and confirmed the lack of structuring and the existence of various organizational deficiencies in the development of text. All in all the students' inability to construct a successful paragraph is due to the lack of a) appropriate syntactic and lexical selection, b) organization of ideas, and c) appropriate strategy that make text both efficient and effective.

\begin{tabular}{|l|l|l|l|l|l|l|l|l|l|l|}
\hline $\begin{array}{l}\text { Language } \\
\text { Skills }\end{array}$ & \multicolumn{3}{|c|}{ Reading Tasks } & \multicolumn{3}{|c|}{ Speaking Tasks } & \multicolumn{5}{c|}{ Writing Tasks } \\
\hline Tasks & $\begin{array}{l}\text { Pre- } \\
\text { Reading } \\
\text { Task } \\
\text { Reading } \\
\text { Task }\end{array}$ & $\begin{array}{l}\text { Reading } \\
\text { Compre- } \\
\text { hension }\end{array}$ & a. & b. & c. & d. & a. & b. & c. \\
\hline $\begin{array}{l}\text { Students } \\
\text { Performance }\end{array}$ & $\begin{array}{c}\text { v. } \\
\text { Good }\end{array}$ & $\begin{array}{r}\text { Good } \\
\text { Good }\end{array}$ & G & o & o & d & nnedium Good low & & \\
\hline
\end{tabular}

Table no. 1 Students' Overall performance

\subsection{Conclusions and Recommendations}

The present section aims at drawing some conclusions arrived at in this study. In addition, some pedagogical recommendations related to methods of teaching, staff 
العدد السادس

training, and classroom instruction will be outlined. Suggestions for further research will also be outlined.

\subsubsection{Conclusions}

The researcher has come up with the following conclusions:

1.) The adoption of CLT in ELT context is stimulating for both teachers and learners. CLT raises important issues for teacher training, motivating- work classes, materials development, and evaluation. CLT can be applied to the teaching of any skill and to all levels of language programme. It is suitable for non-native teachers and equally suited in EFL/ELT contexts. CLT procedures are evolutionary rather than revolutionary. The implication for the learner is that he should contribute as much as he gains, and thereby learn in an interdependent way. 2) Since the aim of ELT courses is to help students to communicate fluently in the target language, teachers should not focus on linguistic benefits only, but also on other benefits. Short stories help teachers to teach literary, cultural, higher-order thinking, and other aspects of literature beside helping students to learn the four skills of languages, listening, speaking, reading, and writing. This is ultimately due to the motivational benefits embedded in them.

\subsubsection{Recommendations}

\section{1) Methods}

More modern methods and classroom techniques should be used which

a) put emphasis on the communication properties of language, b) take care of the necessary feed back, and c) bring students' communicative elements.

\section{2) Textbooks and Teaching Material}

A resource centre of teaching material and textbooks on the teaching the four skills of language should be made available to the practicing teacher and the learner. The teacher can thus select those materials and books that can best serve the learners' needs and promote their motivation.

\section{3) Staff Development Scheme}


العدد السادس

Staff development scheme is required whereby staff members, who have the responsibility of teaching the skills of language, a) take part in practical workshops and seminars, b) participate in summer courses on modern and effective techniques of teaching EFL skills, and c) attend symposiums and conferences on topics of similar nature.

\section{4) Extensive Reading}

Learners should be encouraged to do extensive reading in the library on various topics with aim of a) improving their reading skill, b) improving their vocabulary items, c) exposing them to various written styles, and d) increasing their knowledge of the world.

\section{5) Written Tasks}

The written tasks that are given to learners should be characterized by the following:

a) Interesting and challenging.

b) Communicative in nature and design.

c) Having emphasis on the learners' adoption of the appropriate strategy for developing and organizing ideas.

d) Having emphasis on the structure of the English paragraph, the topic sentence, major support sentences, and minor support sentences.

\section{6) Other recommendations}

To achieve a better quality of instruction and secure a maximum amount of practice, the following requirements are to be met:

a) The size of the class has to be reduced in that the number of the students should be manageable.

b) Frequency of practice, particularly in written practice.

\subsubsection{Suggestions for Further Research}

In connection to this work, research can be carried out to investigate the effectiveness of using CLT in poetry context.

\section{APPENDIX}




\section{The Man Who Planted Trees}

\section{Extract (1)}

About forty years ago, I was taking a long trip on foot over mountain heights quite unknown to tourists. All around was barren and colourless land. Nothing grew there but wild lavender.

After five hours' walking I had still not found water. All about me was the same dryness, the same coarse grasses. I thought I saw in the distance a small black silhouette. It was a shepherd. Thirty sheep were lying about him in the baking earth. He gave me a drink and took me to his cottage on the plain.

I felt peace in the presence of this man. I asked if I might rest here for a day. He found it quite natural—or, to be more exact, he gave me the impression that nothing could surprise him. I didn't actually need to rest, but I was interested and wished to know more about him.

The shepherd puts a large sack of acorns onto the table. He inspects each acorn and carefully chooses one hundred perfect ones before going to bed. The writer is curious. The next day when he goes out with the shepherd into the hills, he discovers what the acorns are for.

\section{Extract (2)}

I noticed that he carried for a stick an iron rod as thick as my thumb and about a metre and a half long. He began thrusting his iron rod into the earth, making a hole in which he planted an acorn; then he refilled the hole. He was planting oak trees.

After the midday meal he resumed his planting. I suppose I must have been fairly insistent in my questioning, for he answered me. For three years he had been planting trees in this wilderness. He had planted one hundred thousand. Of the hundred thousand, twenty thousand had sprouted. Of the twenty thousand he still expected to lose half. There remained ten thousand oak trees to grow where nothing had grown before.

That was when I began to wonder about the age of this man. He was obviously over fifty. Fifty-five he told me. His name was Elzéard Bouffier. I told 
العدد السادس

him that in thirty years his ten thousand oaks would be magnificent. He answered that if God granted him life, in another thirty years he would have planted so many more than these ten thousand would be like a drop of water in the ocean. The next day we parted.

For the next five years the writer is a soldier and fights in World War I. The war ends in 1918 and his thoughts turn again to the tree-planter in the mountains. He returns to look for him.

\section{Extract (3)}

I had seen too many men die during those five years not to imagine easily that Elzéard Bouffier was dead, especially since, at twenty, one regards men of fifty as old men with nothing left to do but die. He was not dead. As a matter of fact, he was extremely well. He had changed jobs. He had got rid of the sheep because they threatened his young trees. For, he told me, the war had disturbed him not at all. He had imperturbably continued to plant.The oaks were then ten years old and taller than both of us. It was an impressive spectacle. I was literally speechless, and as he did not talk, we spent the whole day walking in silence through his forest. It measured eleven kilometers in length and three kilometers at its greatest width. When you remembered that all this had come from the hands and the soul of this one man, you understood that men could be as effective as god in ways other than destruction.

The writer returns for a final visit in 1945 after World War II. Elzéard is still alive. The writer is amazed at what he sees. Not only is there the forest, but many villages have been rebuilt, and by 1953 more than ten thousand people in the area owe their happiness to Elzéard Bouffierr.

\section{Extract (4)}

The bus put me down in Vergons. In 1913 this village of ten or twelve houses had three inhabitants. All about them nettles were feeding upon the remains of abandoned houses. Now everything had changed. Even the air. Instead of the harsh dry winds, a gentle breeze was blowing, laden with scents. A sound like water 
came from the mountains: it was the wind in the forest. Most amazing of all, I heard the actual sound of water falling into a pool. I saw a fountain had been built. Ruins had been cleared away, and five houses restored. Now there were twentyeight inhabitants, five of them young married couples. It was now a village where one would like to live.

When I think that one man was able to cause this land of Canaan to grow from wasteland, I am convinced that in spite of everything, humanity is good. Elzéard Bouffier died peacefully in his sleep in 1947.

\section{The Wisdom of Solomon}

As the two women came to King Solomon to plead their case, one of them spoke first. "I plead with you, Sir, to hear what I have to say!"

"Speak!" said the King. " What is your problem?"

She pointed to another woman who was standing near her with a tiny bay in her arms. "Sire, this woman and I live in the same house. About two weeks ago I gave birth to a son. She helped me. She and I were the only ones there." As she spoke, tears came to her eyes.

"Go on, my daughter," said the King.

Three days later, my lord, this woman also had a baby. And it, too, was a son. I helped her give birth. There were still only two of us in the house." Tears streamed from her eyes as she continued.

"A few days later, her baby died in the night because she accidently lay on it as she slept. And then she took my son from my bed while I was sleeping and put her dead child beside me." She continued to weep as she spoke. "When I got up in the morning to nurse my son, I found that it was dead; but when I examined it, I discovered that it was not my child." "That's not the way it was!" the other woman interrupted. "That's not the way it was at all! She's just making up an emotional story for you, Sire, and she had produced some tears to go with it! This is my son; the dead child is hers!" 
"You're lying!" said the first woman. "And you know it! The living son is mine and the other is hers!"

"Oh no it isn't!" said the other woman, as she held the child close to her. "It's the other way round! This is my son!"

And in this way they argued back and forth in front of the King. Solomon had listened and observed carefully and it seemed as though he had made up his mind. However, he asked the woman to lay the child down in front of him. He looked intently at the child and then at each of the women as though he were trying to determine by appearance whose child it was. Then, to the great surprise to all who heard, King Solomon said, "Bring me a sword. " One of the guards came with a sword in his hands. "Divide the child in two parts!" he said coldly. "Give half to one and half to the other!"

As the guard raised the sword to obey the King, the first woman cried out, "Don't kill the child, my lord! Please don't do it ! Let him live and give him to her."

The other woman, however, thought Solomon's idea was a good one. "Cut it in two!" she shouted. "Then neither one of us will have it!"

Then the King raised his hand and spoke. "Don't kill the child! Give it to the first woman!" he commanded, pointing to her. "She is the mother!"

\section{3. "I'm a Ghostbuster," Says Vicar}

Aelwyn Roberts, 79, used to be a vicar. H's retired now, but he still works as a ghostbuster. He helps people who have ghosts in their houses to get rid of them. 'I'm a kind of social worker for ghosts,' he explains. 'Some people die and they still have problems when they leave this world, so they come back again as ghosts to sort them out. I don't think that ghosts might exist. I know they do exist.'

He says he has met thousands of ghosts trapped between this world and the next. He helps them sort out their problems so they can move on to the next world.

One example is typical. At exactly nine every night a three-year-old boy got out of bed and went downstairs. When his parents asked him to explain why, he said that 
he saw an old man in a funny hat sitting on the end of the bed. The man told him to get out of his bed and go downstairs.

For Mr. Roberts this was simple to sort out. He moved the boy's be from one part of the room to another, 'The ghost was the boy's great-grandfather and the bed was in his way', he explains. The family were never troubled again.

Eighty per cent of the time the ghosts are members of the family. I tell people that if they want me to get rid of them, I might be throwing their grandmother out of the house. I worry that they might miss her.'

Mr. Roberts calls ghosts 'yesterday's people". His advice is simple. 'You just need to tell them, firmly, to go away and leave you alone.'

\section{The Man who Could Turn Back the Clock}

This is a parable with two different endings.

Readers can choose the ending they like best

ONCE upon a time there was a man who had power to turn the clock. Whenever he had regretted something he had done or said, he could repeat the event in the light of experience.

Now one day it happened that this man was out for a walk when it started to rain, so he took shelter in a barn. After a few minutes the man was joined by a very beautiful young lady and her dog, who were also seeking shelter. The downpour lasted for an hour.

The man went home to his wife and told her why he was late. Immediately his wife was suspicious of her husband's behaviour with the young lady. She questioned him about what had happened. The man replied in a surprised and hurt voice: Why, nothing happened. I was a perfect gentleman. What do you expect? Especially when she had such a large dog with her.'

His wife was furious: 'What!! Only the dog stopped you!'

The man realized his mistake and immediately he turned the clock back a few minutes and tried the conversation again. This time when his wife expressed her 
العدد السادس

suspicion, he said 'It's true the girl was very beautiful and she seemed to like me but my deep love for you gave me the strength to resist temptation.'

However, his wife was even more furious: 'What!! You wanted to kiss her! An immoral thought is as bad as an immoral deed.'

1. The man spent a long time thinking. There must be some way to please his wife!

Finally he turned the clock back again a few minutes. Once more his wife asked how he had behaved with the beautiful young lady. But this time he replied: 'What? She wasn't beautiful, she was ugly! I am a man with good taste, which is why I married you, my darling!'

When she heard this, his wife, who in fact was rather unattractive, flung her arms around his neck and cried, 'I love you!'

2. The man felt that his wonderful power had not helped him at all. Except to teach him that it was impossible to please his wife, and he had suspected this for a long time. Therefore he turned the clock back once more, not just a few minutes, a few hours. He went back to the beautiful young lady in the barn, in the rain.

Adapted from a story by

Ralph Milne Farley.

\section{King Arthur}

The legends of King Arthur began to appear in the twelfth century, and it is possible that they are based on a Celtic leader in the fifth or sixth century who defended his country against Saxon invasion. King Arthur was the son of Pendragon, and was born in Tintagel in Cornwall. He was bought up by Merlin, an old Celtic magician, and became king of Britain when he was fifteen. He proved his right to be king when he managed to pull a sword from a rock. He had to fight many lords, and when, with Merlin's help, he defeated them, he received the magic sword Excalibur from the lady of the lake. He married Guinever and lived in a castle at Camelot. His knights sat at a round table so that they were all equalnobody was sitting at the head of the table. Many of the stories in the legends are 
about the adventures of the knights, among them Lancelot, Perceval, Gawain, and Galahad. They spent their time hunting wild pigs, having feasts, and singing ballads. They often had to kill dragons and giants. At all times they behaved very correctly, with respect, honour, and compassion.

Arthur went to Rome to fight the emperor, Lucius, and he left the kingdom in the hand of his nephew, Mordred. As he was entering Rome, Arthur learned that Mordred had taken control of the kingdom and had captured Guinevere. He came back to England and defeated his nephew, but in the battle was seriously wounded. Arthur told Sir Belvedere, the last surviving knight, to throw Excalibur into the water of a lake. He did this, and the sword was caught by a hand which came out of the water and then took the sword below the surface.

Arthur was then taken to the Isle of Avalon to get better. We understand that he did not die, but lives on and will return when his country needs him. The legend says that the following verse is written on his tomb:

\section{HIC IACET ARTURUS, \\ REX QUONDAM \\ REXQUE FUTURUS}

( HERE LIES ARTHUR, THE ONCE AND FUTURE KING).

\section{References}

Allen J. B. and Corder, S. P. (1975) Papers in Applied Linguistics. Vol. 2. Oxford: Oxford University Press.

Allen, J. P. And Widdowson. (1975) Grammar and Language Teaching. Oxford: Oxford University Press.

Bloom's critical thinking questioning strategies. Retrieved on October 15, 2007 from http: // www.kyrene. Org /schools/ brisas/ litpac/ bloom-handout. htm. Brumfit, C. J. And Johnson, R. (1979) The Communicative Approach to Language Teaching. Oxford: Oxford University Press.

Crystal, David. (1992) An Encyclopedic Dictionary of Language and Languages. Oxford: Blackwell Publishing. 
العدد السادس

Elliott., R. (1990) Encouraging Reader-Response to Literature in ESL Situation. ELT Journal 44 (3), 191-198.

Freeman, Diane. (1986) Techniques and Principles in Language Teaching. Oxford: Oxford University Press.

Hudson, R. A. (1996) Sociolinguistics. Cambridge: Cambridge University Press.

Lao. C. Y. And S. Krashen. (2000) The impact of popular Literature Study on Literary development in EFL. System, 28, 26-270.

Littlewood, W. (1981) Communicative Language Teaching. Cambridge: Cambridge University Press.

Murdoch, G. (2002) Exploiting Well-known Short Stories for Language Skills Development. / ATEFL LCS S/G News Letter 23, 9-17.

Oster, J. (1989) Seeing with Different Eyes: Another view of Literature In ESL Class. TESOL Quarterly, 23 (1), 85-103.

Richrds, Jack C. and Theodor B. Rodgers. (1986) Approaches and Methods in Language Teaching: A Description and Analysis. Cambridge: Cambridge University Press.

Santon, Robert (1965) An Introduction to Fiction. London: Holt, Rinehart and Winston, INC.

Soars, John and Liz (2005) Headway. Oxford: Oxford University Press. 